\title{
HYPHY SPARKED A SOCIAL MOVEMENT
}

\author{
Andrea L.S. Moore \\ California State University, Sacramento
}

\begin{abstract}
"When hip hop's true influence as a cultural movement is finally understood. . .people will recognize that the very same synergy at the heart of hip hop's commercial success has also informed our generation's activist and political theorists."
\end{abstract}

-Baraka Kitwana

Hyphy (pronounced Hi-fee), is a genre of rap and lifestyle associated with Bay Area hip hop culture that emerged in early 2000 and by 2009 evolved into a counter-cultural social movement for marginalized youth. Hyphy was originally a part of Bay Area vernacular used in local neighborhoods as an actual hyperbole on the word hyper. It eventually came to mean an unbridled release of energy that could include excitement, frustration or uncontrolled anger. The synergy of anger mixed with raw and aggressive sounds in the musical beats created a powerful reflection of street life and party style rap. ${ }^{1}$ The aesthetic dimensions of Hyphy include sideshows (car culture), slanguage (language), turfin' (dancing), fashion, and the independent hustling/marketing of an artist. Each aesthetic is heavily influenced by the everyday reality one experiences while living in urban spaces. The dynamism of Hyphy is carefree resistance; the sound, in combination with the everyday marginalized lived experiences. The Hyphy Movement emerged as a collective for activism as "Baydestrians" (residents of the Bay Area) became widely dissatisfied with their historical lack of social power and economic resources, and with systematic institutional oppression.

The Bay Area is an epicenter for marginalized social movements and Hyphy may be understood as a seed of the legacy of this region reaching back to the 1960's Black Power Movement and leading towards the Black Lives Matter Movement. While conceptualizing Hyphy as a hip hop counter cultural social movement it must be understood that it

1 Hyphy was not initially meant to become a commercialized movement per se, it was simply a slang term to express a style, a feeling, an energy, to describe aesthetics known to Bay Area hip hop for years. As a response to the death of Mac Dre, and corporate co-optation of Hyphy aesthetics, Bay Area youth and a few rappers helped solidify the Movement. Rappers held the power to channel that frustration and creativity and they used the movement to do just that. Oakland artist Keak Da Sneak, or Charles Toby Bowens (also known as King of the Supa Dupa Hyphy Hyphy), was the first rapper to use the term Hyphy on the song "Cool" from his 1998 album Sneakacidle 
did not come out of a vacuum. It stands on the shoulders of past Bay Area counter culture movements and revolutionary protest demonstrations that took place in prior generations.

For over half a century, the Bay Area has been home to resistive social movements, and is known in particular for opposing marginalization and police violence. The Black Power Movement, Black Panther Party for Self Defense (BPP), the Hippie and Black Arts Movement (BAM), and now the Hyphy Movement share seeds of the same legacy of youth activism. The previous movements took precedence for involving young people in opposing the authoritative systems that violently controlled social economic rights and civil liberties and the latter has continued. As a result of the past movements mentioned there developed a distinctive social consciousness for which the Bay Area became known. Issues with policies about the "War on Drugs," the "War on Gangs," spatial politics, gentrification, and complex legislation that targeted urban spaces, thereby created social tensions between the police and many Black communities in the Bay Area. The issues and concerns represent not only the backdrop from which hip hop emerged, they are what Hyphy later built upon and constitute several protest platforms relevant in the movement for Black lives.

The historical context of past protests and social resistance connects the role of youth to contemporary movements that also validate cultural expression as a form of protest for youth struggling to gain freedom from unjust social oppression. In 2006 hip hop scholar S. Craig Watkins suggested that, "While the activist impulse in the Bay Area's hip hop scene can be partially attributed to the rich history and culture of social movements in this region, it also comes at a time when many young Californians have been pushed to the brink." ${ }^{2}$ Indeed Watkins argues correctly, almost anticipating the rise of the aggressive Hyphy Movement in his reflection on the Bay Area. Hyphy-associated rapper Mistah F.A.B. is well aware of the historical connection the movement has with Bay Area resistance, he states, "You can go back as far as the Panthers, the hippies, a lot of those things started right here." 3 The descendants of those movements make up the third generation of youth in the Bay. Moreover, this region has a history of cultivating resistance movements that are organized by the power of socially marginalized minorities and college age youth.

2 S. Craig Watkins, Hip Hop Matters: Politics, Pop Culture and the Struggle for the Soul of a Movement, (Boston: Beacon Press, 2006), 164.

3 T-shirts are sold with the message of "Home of the Black Power Movement and Home of the Hyphy Movement" T-Shirt Orgy-Bear Basics: World's Largest T-Shirt Store 12350 Telegraph Avenue, Berkeley. 
Past Bay Area historical movements created the pathway for hip hop to follow in the footsteps of outspoken activists and poets in a post Black Power era as they began to express the issues still affecting many urban communities. Molefie K. Asante Jr. describes the energy of progressive hip hop, "the force that created Malcolm was the same force that created hip hop, a visceral energy aimed at transforming, (or at least voicing) the conditions of oppressed people."4 For marginalized young people in the Bay Area in particular, the ideals of the Nation of Islam or the Black Power Movement represented community protection against police violence, the promotion of Black pride and love, economic selfsufficiency, independence, knowledge-of-self, and use of art as a political tool for expression. The youth were surrounded with these extant ideologies and messages because they lived in the same conditions that never changed in substance. These same messages that had educated previous generations about their social positioning in America resurfaced in rap music and evolved into a new generation's struggle for a self-defined liberated identity. Hip hop became the most viable lifestyle for the marginalized youth to pursue the goal of liberation. "This was not simply hip hop's promise but hip hop's reality."5 The influence of rap culture and its overall message of free speech, resistance and alternative modes of attaining equality attracted rapper Tupac Shakur whose career can be perceived as picking up where the Black Power Movement leaders left off. Much of his rap's content was about refuting the systems of oppression he felt were entrapping Black people. As hip hop is noted for birthing generations that challenge historical hegemonic perceptions of Black youth, the Bay Area's organizations that provide direct services to youth began to utilize hip hop and later the Hyphy Movement to give voice to those who endured the politics surrounding youth criminalization.

For example, grassroots projects that began occurring at the end of the 90s gangster rap crusade which began to utilize hip hop to tackle police violence carried over into the early 2000s. Before the Hyphy Movement, young hip hop activists had taken to the Bay Area streets to fight reoccurring injustice in two major events. First, 1996-1997 was the grassroots campaign known as Justice for Aaron Williams and second, a year later they began a long fight against the Gang Violence and Juvenile Crime Prevention Act Prop 21 of $1998 .^{6}$

Justice for Aaron Williams was a foundational campaign for hip hop organizing. In 1995, San Francisco police officer Marc Andaya killed an

4 Molefie K. Asante Jr., It's Bigger Than Hip Hop: The Rise of the Post Hip Hop Generation, (St. Martin Press, New York: N Y, 2008), 10.

5 Ibid

6 The Ella Baker Center, Accessed June 10, 2010. http://www.ellabakercenter.org/page .php?pageid $=19 \&$ contentid $=152$ 
unarmed Black man, Aaron Williams. Andaya led a team of cops who viciously beat and kicked Williams, emptied three cans of pepper spray into his face, and finally hogtied him in an unventilated police van where he died. ${ }^{7}$ The Ella Baker Center for Human Rights founded in 1996, (made up of several initiatives serving the community youth with ties to hip hop activism and street culture) responded by documenting, challenging and exposing such abuses, leading the fight for justice for Williams. ${ }^{8}$ "The founder, Van Jones, led his team through two years of organizing and protesting against the way in which officer Andaya was portrayed as the victim. The police went so far as to have a medical examiner argue that Williams died from "Custody Death Syndrome" (the shock from being in custody somehow kills the detainee). The Center demanded that the officer be fired and eventually he was. This community win led the Center to launch a youth group called the Third Eye Movement. "With innovative, militant, non-violent direct action, Third Eye Movement became a national example of a new generation of hip hop activism."9

The Ella Baker Center utilized hip hop as a strategic tool to connect youth with electoral politics and used the media for creating change in the judicial system making youth feel a part of and needed in the community. The Center understood that the hip hop generation was in need of uplift more than ever and thus organized around benefiting marginalized youth. "Due to gross racial disparities in the juvenile justice system, it is primarily families and communities of color that have to pay the cost of DJJ's abuses. Of the 1,950 youth in DJJ prisons as of July 2008, 87\% are young people of color. And virtually all of the kids inside are from low-income backgrounds." 10 They reignited hip hop activism and created several initiatives dedicated to the youth, such as Silence the Violence, Heal the Streets, and the Urban Peace Movement. One of their largest

7 Pepper spray has been involved in over 60 deaths of people in police custody nationwide. Many of the SFPD pepper-spray procedures were put into effect in response to outrage at the police murder of Aaron Williams in 1995. Mark Garcia a 41 year old teamster also died like Aaron Williams, after being beaten, pepper-sprayed and hog-tied by the police. William Bowser, Aaron Williams' uncle, was angry at how the police ignored the rules put in place after Aaron's murder. "These things were put into place after the murder of Aaron. They worked 6, 7, 8 months, a year to figure out how they're going to keep people from dying-you weren't going to do this, you weren't going to do that. But somebody decided to do whatever he feels like doing."

Revolutionary Worker \#967,"Struggle Against Police Murder in San Francisco: People Demand Justice in Mark Garcia Case," Revolutionary Worker Online, July 26, 1998 Accessed June 11, 2010. http://rwor.org

8 In 1995 a Bay Area grassroots organization Bay Area Police Watch emerged by attorney Van Jones launched the hotline for victims of police brutality under the auspices of the Lawyers Committee for Civil Rights. He later developed it into the Ella Baker Center.

9 Ibid.

10 The Ella Baker Center, Accesed June 11, 2010. http://www.ellabakercenter.org/page .php?pageid $=18 \&$ contentid $=7$ 
political campaigns involving youth was the Books Not Bars Stops the 'Super-Jail' in 2001-2003. This campaign was a response to Governor Wilson's public rhetoric about Prop 21 being made for "young superpredators," as well as the investigations that revealed the deplorable violence amongst youth at the California Youth Authority (CYA) later renamed The California Division of Juvenile Justice (DJJ). These events foreshadowed social and political protests that would again occur during the height of the Hyphy Movement.

The Ella Baker Center was one of the first organizations that used the Hyphy Movement as a strategic tool to address the social tensions among the youth and to coordinate workshops and curricula. More specifically, The Silence the Violence campaign utilized the Hyphy Movement and some of its rappers to target youth political participation in voting and in reducing gun violence.

\section{“A'INT SHIT CHANGED CUZ OBAMA IN THE HOUSE"11}

Bay Area rappers associated with the Hyphy Movement such as, Too \$hort from East Oakland, San Quinn from Fillmore in San Francisco, Mistah F.A.B. from North Oakland, Beeda Weeda, and a host of other iconic Bay Area rappers joined others to contribute to the youth's awareness and promotion of 2008 presidential election voting. The residual grass roots efforts for the political campaign, "Vote Fa-Sheezy" later entitled, the "Wake Ya Game Up" was led by organizations such as, Youth UpRising, Hip Hop Congress and a host of others who worked with the hip hop generation to promote President Obama's election. Hyphy functioned, as Mass- society theory suggests, as a social movement that has dual purposes serving both personal and political agendas, attracting socially isolated people who join in order to gain a sense of identity and purpose. ${ }^{12}$ Regardless of whether they were old enough to vote, Hyphy youth took part in the election campaign process because it allowed them to realize, and reconstruct the meaning of who they are collectively. It also empowered them with a sense of hope that their lives had meaning in their communities. "They utilized hip-hop radio stations, recording industry street teams, web and pod casts, social networks, blogs and grassroots organizing to move youth to vote."13

11 Mistah F.A.B. and Amp Live (Zion I) - "Oscar Grant III Tribute (My Life)" ft. Jennifer Johns \& Codany Holiday, January 2009.

12 Alberto, Melucci, Nomads of the Present: Social Movements and Individual Needs in Contemporary Society, ed. John Keane and Paul Mier. (Philadelphia, PA: Temple University Press, 1989).

13 Michelle Wong, Sarah Ingersoll and Marisa Murgatroyd, "2008 Election Media Report," Meaningful Media, October 8, 2008. 
While the rest of America began to celebrate the start of a supposed post racial society due to Barack Obama becoming the first Black president of the United States, the Bay Area, however, was once again outraged by a devastating reality that not much had changed at all.

A man becomes president who looks like me for the first time ever, while a man who looks like me is shot in his back in East Oakland. Even though there is a Black president, a Black male can still be shot in the back by the police. There is something to be said about these two events happening so close to another. Barack Obama was sworn in January 20, 2009 and Oscar Grant 3rd was executed January 1, 2009. There was an unrealistic euphoria/delusion that everything would change because the President was Black. These thoughts came from a pivotal conversation I had with a young black female Harvard Doctor, Mrs. Vajra Watson, coordinator of the Sacramento Area Youth Speak (SAYS Project), a spoken word group. While attending one of the youth speaks event I began to notice that student after student included the tragic death of Grant in their spoken word poems explaining how it affected them.

Oscar Grant III was a twenty-two-year old father who was murdered by Bay Area Rapid Transit System (BART) police officer Johannes Mehserle New Year's Day 2009. His actual murder was recorded on several cell phones and instantly uploaded on to YouTube garnering viral exposure. "Grant's death was the first high-profile police shooting in a generation, and the first in which social media played a pivotal role in the organizing that followed." (Cullors 2016). ${ }^{14}$ After being, harassed, beaten, and sprayed with mace, he was placed in handcuffs while lying face down on the ground. Fruitvale station officers Tony Pirone and Mehserle were the authorities involved. Pirone placed a knee in his back and Mehserle allegedly attempted to restrain Grant while pulling out his firearm, and shot him in the back. The Bay Area was furious that yet another unarmed Black male had died at the hands of an officer. ${ }^{15}$ There was a clear shift in political discourse from voting for Democrats to a more traditional militant and radical critique of the organization of the state and the police.

\section{Police kill at will}

They killed Oscar Grant, they killed Bobby Seal 16

14 Black Lives Matter Co-Founder Patrisse Cullers "Cephus Johnson and the men of Black Lives Matter"

Oakland North, April 7, 2016. July 11, 2016.

15 Anthony W. Neal, Unburdened By Conscience: A Black People's Collective Account of America's Ante-Bellum South and the Aftermath, (University Press Of America, 2010).

16 Mistah F.A.B. and Amp Live (Zion I) - "Oscar Grant III Tribute (My Life)" ft. Jennifer Johns \& Codany Holiday, January 2009. 
The young people in the Bay Area utilized hip hop aesthetics to express their reaction to the Grant's murder. The Oakland organization Urban Habitat, created a project called Race, Poverty and the Environment / RED! and with Media Alliance they co- sponsored "The Oscar Grant Memorial Arts Project." The project provided a public and digital space for the community to creatively express their feelings about the murder. It was a time for unification; the editor of Race, Poverty \& the Environment, B. Jesse Clarke, had this to say,

People are angry. Thousands have been appalled by the Oscar Grant shooting and have taken a new stand to fight injustice. Many have chosen to creatively express their stance through art. Songs have been written and dedicated to Oscar Grant. Poems, paintings and posters have been created. Graffiti artists have painted murals. Some of this is compelling art, some is ephemera. Some of this art is controversial in its subject matter or its expression, but above all this art is the expression of a critical moment in the movement to end police violence. ${ }^{17}$

Grant's murder hit home with many diverse ethnic groups who are transnationally connected to what Melanie Cervantes and Jesus Barraza's Oscar Grant poster refers to as, "Government Sponsored Murder in the Ghetto." Their artwork entitled, "Justice for Oscar! Justice for Gaza!" an inscription under the painted portrait of Grant states "End Government Sponsored Murder in the Ghettos of Oakland and Palestine." 18 The artists' message linked the similar outcry for the historical and violent imperialism against marginalized Palestinians and the marginalized Black and Latino youth involved in Bay Area hip hop culture. Although a local tragedy, Grant's murder affected people nationwide.

The murder created social tensions that led to an "us against them" environment; it separated the community between local supporters of the police and freeing Mehserle of all charges, against those supporting political justice for Grant and others like him who died from the hands of police brutality. Due to Grant's murder receiving national social media attention it provided a platform to address police brutality and the criminal justice system in the United States. During the public debates about the killing, many conflated arguments were made about police jurisdiction, race, and youth criminality. For example, being an Oakland police officer is different from being a BART police, but the Oakland Police

17 Urban Habitat: Race Poverty and the Environment / RED! Is the journal for social and environmental justice. RP\& E publishes news, views and analysis of the social and environmental justice movements. Accessed September 19, 2010. http://www.urbanhabitat.org/taxono my/term/187?page $=3$

18 http://dignidadrebelde.com/blogpost/view/88 
Department (OPD) was faulted because of similar occurrences. The murder of Oscar Grant questioned a very problematic, both conservative and liberal, notion of post-racial nostalgia. The murder illuminated the reality of police brutality and was often juxtaposed with the Obama political moment of presumed hope and change. It became a dichotomous storyline, paralleling the countless articles about Barack Obama, African American "progression" and the lack thereof. The marginalized youth chose not to remain silent, and instead challenged police brutality and held the judicial system accountable for discriminatory practices for criminalizing Grant. As Oscar Grant was only twenty-two years old, he was considered very much a part of hip hop's third generation and this cohort was particularly affected by his death. Upon hearing the news, many young people immediately took to the streets to protest and riot about what they understood to be a typical repeated violent act against Black youth. The protests took place for weeks at a time.

First you didn't give a fuck, but you learnin now If you don't respect our town, then we'll burn you down

God Damn, it's a mutherfuckin riot

Black people on a rage, police so don't try it! 19

\section{Am Oscar Grant}

Many of the youth involved with Hyphy culture were a part of the angry crowds who protested against the injustice for Oscar Grant. Over 100 Oakland business properties were damaged and hundreds of young people were detained. The Oakland Police Department (OPD) was unsuccessful at crowd control and after several days of protesting and rioting affecting the morale of the community, an intervention was needed. Various non-profit Bay Area community organizations and Bay Area rappers were called on to calm and control the youth. An organized protest rally for Oscar Grant took place on January 7, 2009 at the Fruitvale BART station. The young people needed leaders that they actually believed in to let them know that someone understood their anger and to help them to figure out how they could seek justice and hold the officer accountable for Grant's murder. Mistah F.A.B. and Baba Zumbi from Zion I and the Burnerz) were the spokesmen during a portion of the rally. Both artists are known for their community activism, working with Oakland's community transformation organizational hub, Youth UpRising and the Ella Baker Center's for Human Rights, Silence the Violence campaign to bring peace to the streets. These rappers understood that in order to politically engage the youth, the information presented must address

19 Tupac Shakur, "I Wonder if Heaven Got a Ghetto," $R$ U Still Down (Interscope/Jive Records/Amaru Entertainment, 1993). 
their needs. This form of validation is what makes hip hop so influential and relevant to young people.

Huey tried to motivate the people, Take a stand against the prejudice evil, He had us going, had the city rallied up Black Panthers, Black Power, and look how they do us. ${ }^{20}$

At the rally, F.A.B. focused on several sides of the crisis, he first addressed the anger the protestors felt. He also addressed critics of Hyphy for misunderstanding and narrowly depicting the culture and his role in it. The connection between the Hyphy Movement and protests for Grant are highlighted below as an ethnographic transcription of conversations that took place at the rally.

Mistah F.A.B.: "We say fuck the police" if they not gonna protect us!"

"Everyday we fear our lives, and then they wonder why the youth is so corrupt. I don't believe in bad kids. I believe that every child has had an adult that has lead to its delinquency and contributed to the mischievousness of that child.

In the city we live in we are being patrolled by Hitler's. . .assassins, murderers. For us not to react the way that we react would be ignorant. . .(sic)

Yea they say Mistah F.A.B. well you're Hyphy and you're the reason why a lot of these kids are like that. Yea right! We're radiation and chemical babies. I'm a, I come from a family just like many of you. My dad died from AIDS. . . my mother recently, two days ago, just found out that she has cancer. Now I'm bearing my heart to the people to let you know I m just like y'all. When they see me walking thru this crowd they like, is that? It's not about me today. I am Oscar Grant. Today I am a voice that wanted to tell you something that you should have heard a long time ago."

F.A.B. drew on historical connections of identity politics speaking against youth criminalization. His comments shed light on the role police play in shaping their relationship with youth based on criminal perceptions. F.A.B. addresses unification stating, "I am Oscar Grant!" This 
statement is symbolic of the "I am Malcolm X" and "I am Fred Hampton" references often stated by members of the community after both of the leaders were murdered. "I am Oscar Grant" symbolizes a unified identity of solidarity, and F.A.B. confers that if it could happen to Grant, it could happen to any of them. Because it happened to Grant, it happened to all of them, suggesting that when the police unjustly murder one, the community suffers from the lost as a whole. In addition, the symbolic phrase gives life to the dead - - Grant may be deceased, but his legacy lives on within those who remember him and seek justice for his wrongful death. "I am Oscar Grant!"

In My Life I never give up,

In the Morning comes the Sun,

Im a survivor,

You a survivor

Im a survivor

He a survivor

She a survivor ${ }^{21}$

Next Mistah F.A.B. introduced Baba Zumbi (AKA Baba Zumbi AKA MC Zion, original member of Zion I),

Baba Zumbi- "One love, family how y'all feel? Man I know the New Year just started but this is not the way to start." "Hell naw!" A crowd member yells.

"But I am glad to see all of the faces out here. This represents that we still a community now no matter what the media tries to say, no matter how much we fight each other. We still love each other and this is evident of that. We community we stand strong. We stand strong in the memory of Oscar Grant. We saying fuck the police! Fuck the police if they not gonna protect us. Say it. Fuck the police!"

In true call and response formation the crowd begins to chant Fuck the police!

Baba Zumbi- "We gotta stand strong its our time to rise up!"

I'm glad to see other hip hop artists. I'm glad to see the youngsters. I'm glad to see the animals out here representing for ourselves. This is Oakland California. Home of the Black Panthers and we need a new movement to 
represent right now, what's happening on the street right now!"

In the spirit of the Black Panthers Self-Defense Ten-Point Platform and Program, Zumbi asserts the demands of the community.

Baba Zumbi: "Today we take a stand against police brutality.

- We demand that BART call for the criminal persecution of all officers responsible for the death of Oscar Grant the III.

- We demand that BART turn over the investigation of the murder Oscar Grant 3rd to the Federal courts.

- We demand that BART hold a public forum to listen to community concerns and develop a set of appropriate policy changes to insure that this never happens again.

Oakland California stand up in the memory of Oscar Grant. Rest in peace. This is love right here, let's keep it moving yall. One Love." "No Justice No peace, the crowd chants."

When Zumbi yells out "Fuck the Police!" he is echoing hip hop group N.W.A.'s 1988 rap "Fuck the Police." The phrase was in response to the social tensions and lack of authoritative respect between poor urban Black and Latino youth for the LAPD's historical record of brutality. The song also foreshadowed the riots in L.A. after the 1992 verdict of Rodney King who became famous for being beaten mercilessly by the police. Both violent attacks (of King and Grant) were caught on film and helped bring national attention to each atrocity. The lyrics articulate a hood narrative understood by many urban poor who see police brutality as a social norm in their communities and N.W.A. were one of the first to bluntly voice their anger of this reality in commercial rap. "The much quoted rap from that album, 'Fuck the Police,' became the target of an FBI warning to police departments across the country. . ."22

Fuck the police, comin straight from the underground.

A young nigga got it bad 'cause I'm brown

And not the other color, so police think,

They have the authority to kill a minority. . . ${ }^{23}$

Michael Eric Dyson discussed the track in relation to the heightened awareness not only to the legalized policing of hip hop in general after the success of the rap, but also the role of rappers and Black victimization. According to Dyson, "Group's like N.WA. should be critically

22 David Samuels, "The Rap on Rap: The "Black Music" that Isn't Either." That's the Joint!

The Hip-Hop Studies Reader, Eds. Murray Forman and Mark Anthony Neal, (New York: Routledge, 2004), 151.

23 N.W.A. "Fuck the Police," Straight Outta Compton, (Priority/Ruthless Records 1988). 
aware that blacks are victims of the violence of both state repression and gang violence, that one form of violence is often the response to the other, and that blacks continue to be held captive to disenabling lifestyles (gang-bangin,' drug dealing) that cripple the life of black communities." 24 Dyson's point is well taken but what happens when the assumed context is not referencing the social responsibility of law enforcement authority? Grant was not in a gang, nor was he a drug dealer, yet he was murdered from the hands of such authority non-the-less.

\section{Cause my city's frustrated they gon ride tonight!25}

For a time the rally was peaceful, but as night approached different crowds of angry youth emerged and the slogan "no justice no peace" was literally enacted. The local news did not cover Mistah F.A.B. and Zumbi's speeches at the rally, but countless headlines noted the riots. A few months after this rally, both artists created raps dedicated to Oscar Grant. Mistah F.A.B. and AMP Live released "My Life" in honor of Grant, and The Burnerz, also released, "Cops Hate Kidz." A poignant statement in an interview with Zumbi summarized the mood of the moment. "It is our hope to fuel discussion about ways that the police can better 'protect and serve' the community, rather than abuse and exploit their power. As we move towards a 'new America,' it will be important that we learn to work together. The old models are falling before our eyes. This is our opportunity to engage change."26

The January 7, 2009 event would not be the first or last of protest rallies, concerts, and town hall meetings to address the murder and the community's concerns that ultimately justice would not be served, if Mehserle would not be convicted for murder. On January 13, 2009 over 2000 people joined to protest once again, the murder of Grant. With Obama t-shirts and fists in the air, they condemned the city officials for mishandling the investigation. The event was under surveillance with six helicopters and hundreds of police, some of whom were videotaping footage of individual activity at the event. Rapper Too \$hort came out to the rally as someone who had the influential power to control the crowd long enough to explain that violent riots would accomplish nothing but more youth persecution. Here is a transcription of Too \$hort's speech in which he cautiously promoted non-violence at the rally.

24 Michael Eric Dyson, "The Culture of Hip Hop," In That's the Joint: The Hip Hop Study Reader. Edited by Murray Forman and Mark Anthony Neal. (New York: Routledge, 2004), 65.

25 Mistah F.A.B. and Amp Live (Zion I) - "Oscar Grant III Tribute (My Life)" ft. Jennifer Johns \& Codany Holiday, January 2009.

26 Jennifer Marston, "MC Zumbi Responds to Oakland Violence," XLR8R Magazine, April 82009. 
I just came out here to speak on the fact that you know, it's a very very very very intelligent effort put in on this day right here for this protest to go down. It would just be so sad if it turned out to be violent today. I just want to say in your love for the town, today on this day let's do this one right. Because everybody's watching us and they want to go back and say "oh them folks from Oakland they wild they don't know how to act." You know what I mean? And I just want to show the world that Oakland, California is a place where we stand up. So let's show 'em with this right here today how we get down! Straight Love! Town Business!

The San Jose Chronicle covered the event and reported the call and response chant was facilitated by the youth. "A group of Original Scraper Bike riders showed up, one of them pumping Hyphy hip hop through handlebar-mounted speakers. Many in the crowd heeded a call from organizers to chant, "I am Oscar Grant." 27 After speeches from other key figures in the community, the protestors marched from City Hall to the Alameda County DA's office and back.

Protest concerts were also held to raise money for Grant's family and their legal matters. While national headlines were no longer running the story about Grant, a small community of local journalists continued to cover events as important news features. On February 27, 2009 a group of hip hop artists organized a birthday celebration for Oscar Grant and proceeds went to his daughter. Artists such as Too \$hort, Ise Lyfe, Zion-I, Casual, Sellassie and Jennifer Johns made special performances. Beeda Weeda and J Stalin performed their new version of "Fuck the Police, and We Ain't Listening." The Bay Area hip hop community was one of the largest supporters for justice for Grant. Eric K. Arnold stated that, "In death, Grant has become a poster boy (literally) for the case against police misconduct, as well as a hip-hop generation martyr." 28 Therefore, despite the exaggerated stereotyping and social critique of Hyphy culture and its supporters, the collective sparked a social movement fostering social and political change against police brutality excessive violence amongst the youth and would lead the way for such issues to be discussed in the Black Lives Matter Movement just a few years later. "Organizers say that the lawsuits and protests that followed helped

27 Todd R. Brown, "Oakland Stands up and Says, 'I am Oscar Grant," San Jose Chronicle, January 142009.

28 Eric K. Arnold, "Oscar Grant B-Day Party at Black Dot Café.” San Francisco Weekly. February 272009. 
lay the groundwork for Black Lives Matter" (Oakland North, April 16, 2016). ${ }^{29}$

On July 8, 2010, Johannes Mehserle was convicted of involuntary manslaughter. Despite the community support from organizations, the youth, hip hop activists and outside followers of the case, the system once again protected the police. It was the calm before the storm because the final response from the community would be based on the final sentencing. ${ }^{30}$

Community organizers began to work with activists to promote peaceful protests and demonstrations. A month before the sentencing was scheduled, the Ella Baker Center for Human Rights hosted an Emergency Leadership Forum. It included a host of hip hop activists, organizations, and other young leaders in Oakland. It was organized with Youth UpRising and the Urban Peace Movement, its purpose was to inform the younger generations about the status of Grant's legal case. In addition, the organizations used the forum to also provide education about the history of social movements and the power they produce. Most importantly, the forum provided the young people with tangible ways of implementing strategy as a plan of action. The organizers involved demonstrated that they valued the youth and understood that the younger generation had the wisdom to offer their own solutions in dealing with such issues. ${ }^{31}$ Youth UpRising had its teens create a multimedia national PSA with local community figures of all generations stating that "Violence is not Justice." Their intention was to prevent violent riots from breaking out after the verdict was released. ${ }^{32}$

However, their intentions to promote non-violent responses were muted on November 5, 2010, when Mehserle was sentenced to 2 years in prison for involuntary manslaughter. ${ }^{33}$ Mehserle's lawyer argued for pro-

29 https://oaklandnorth.net/2016/04/07/cephus-johnson-and-the-men-of-black-livesmatter/

30 The court established Mehserle committed a lawful act but with "criminal negligence." Mehserle committed a crime - using excessive force on Grant by deciding to shock him with a taser - that was not in itself potentially lethal, but became so because of the manner in which it was committed. His possible punishment could have been two, three or four years, four or 10 years for using a gun. The minimum total sentence would be five years and the maximum would be 14 years. He was able to get probation because of involuntary manslaughter. California law requires an increased prison sentence for using a gun during a felony, but it is not clear whether that law overrides another statute that allows probation for manslaughter in unusual cases. In this case the gun enhancement was thrown out because Mehserle was a BART Police officer.

31 Jakada Imani, "Justice or Just Us? Beyond the Hype of the Mehserle." San Francisco Chronicle, July 12010.

32 Davey D. "Violence Is Not Justice! Oscar Grant Killing — Johannes Mehserle Trial" -PSA Daily Hip Hop News. July 12010.

33 The "enhancement" law usually automatically increases the sentencing, but the jury ruled that Mehserle might have mistaken his pistol for a taser, which has been the former 
bation, with no prison time. Counting the 292 days he had already served meant Johannes Mehserle would legally be out of prison seven months after his sentence.

The youth frustrated they feel like its no hope!. . .

You killed somebody son, you killed somebody folks, You killed somebody daddy, but do you care Hell no! ${ }^{34}$

Protestors took to the streets holding signs chanting hip hop slogan, "Fuck the Police," and "We are All Oscar Grant!" Over 150 Oakland protesters were arrested. The downtown streets were filled with angry youth who appeared helpless in their fight for justice. ${ }^{35}$ Grant's family attorney John Burris summed up the historic case and what it meant to African Americans in particular. Because the justice system did not give Mehserle the maximum sentence, this sent a message to African Americans not just in the Bay Area but also throughout the country "that their life is not worth the same as someone else's that is killed under the same circumstances." 36 It would be this statement that resonates with Black lives mattering. This resounding message resulting from an unequal distribution of criminal punishment becomes the impetus for what the hash tag created three years later echoed. The criminal justice system continues to legally demonstrate their hegemonic ideology that does not believe Black youths' lives are worth protecting as a means of social justice and equality.

Here on earth

Tell me whats a black life worth

A bottle of juice is no excuse, the truth hurts

And even when you take the shit. ${ }^{37}$

In the case of Oscar Grant III, the criminal justice system, so often rapped about in hip hop, is once again called into question. The system-

BART officer's defense since the trial. The Los Angeles County Superior Court Judge Robert Perry, who chose not to employ it, threw out the enhanced sentencing that can be brought to bear in a case where a firearm was used.

34 Mistah F.A.B. and Amp Live (Zion I) - "Oscar Grant III Tribute (My Life)" ft. Jennifer Johns \& Codany Holiday, January 2009.

35 "At war with the system. We as a family have been slapped in the face by this system that has denied us the right to true justice. We truly do not blame the jury we blame the system. The jury was denied evidence. Months earlier when the verdict was released on June 8, 2010 Grant's uncle Mr. Johnson reported some of the evidence that was not used in the case like Tony Pirone's racial epithets used during the incident. Mehserle had previous complaints of excessive violence filed against him. He beat up an African American male 45 days before killing Oscar Grant and we can't talk about it?' Cephus Kenneth Bobby Johnson.

36 John Burris Attorney of Law. November 5, 2010.

37 Tupac Shakur, "I Wonder if Heaven Got a Ghetto," $R$ U Still Down (Interscope/Jive Records/Amaru Entertainment, 1993). 
atic killing of unarmed Black people speaks to the social tensions and frustrations vehemently expressed in the marginalized Hyphy culture.

Immediately after the sentence was handed down on November 5, 2010 a press conference was held where Grant's family was questioned by news media. The spokesman of the family, Mr. Cephus "Uncle Bobby" Johnson, spoke of his perception about the system's support of Mehserle, but not Oscar Grant. For him, Mehserle symbolized the police and Grant represented the marginalized community.

"The President of the police union made a discretionary call to represent Johannes Mehserle who is an ex-police officer. This was unprecedented. Everything in this case has been unprecedented. The reason why he did that was because of the significance that this case meant to police officers across the United States. This whole intent was to do the best fight so that he would not be incarcerated or receive any prison time." 38

Cops give a damn about a negro

Pull a trigga, kill a nigga, he's a hero. ${ }^{39}$

Despite the verdict, a legal change did occur due to the public outcry of injustice demonstrated in over twenty community meetings that discussed disdain with the verdict and murder of Grant. On Jan 1, 2011, exactly two years after Grant's murder the "BART Police Oversight Bill" was signed into law. The bill introduced by Alameda Democratic Assemblyman Sandri Swanson was passed into law allowing the board to establish a contract with an outside independent police auditor and a citizen review board. Lynette Sweet, a member of the BART board of directors, explained that, "These entities will work together to improve transparency following certain incidents, such as the use of force by an officer or a discriminatory charge. Sweet also said that if the auditor and citizen review board had existed on the day Grant was killed, events directly following the shooting would have transpired differently." 40

In My Life I never give up, In the Morning comes the Sun,

Im a survivor,

You a survivor

Im a survivor

38 Rita Williams, Video: Mehserle Trial: "Family Members Of Mehserle, Grant React To Guilty Verdict." November 4, 2010. http://www.ktvu.com/download/2010/0709/24190870.pdf

39 Mistah F.A.B samples this quote in the Oscar Grant tribute, "My Life" which is originally from Tupac Shakur's, "I Wonder if Heaven Got a Ghetto," $R$ U Still Down (Interscope/ Jive Records/Amaru Entertainment, 1993).

40 “BART Police Oversight Bill Signed Into Law," WATCH LIVE: Bay Area News At 7 KTVU.com. July 16, 2010. 
He a survivor

She a survivor

This goes out to all the Oscar Grants all over the world We aint goin nowhere, we right here. ${ }^{41}$

Hip hop activism in the Bay Area served as an alternative outlet to address the violence affecting the youth. Moreover, the community's collective who associated with the Hyphy Movement provide insight as to why these modes of reaction, influence contemporary Bay Area youth culture. "Hip hop was created as a vehicle of expression by a community who felt their voices were unheard by the masses, and getting Hyphy is the Bay's way to scream at the rest of the world." 42 Hyphy music culture is a response to the policing of the environment, and it was a radical response to the pathological number of deaths of young Black males by the hands of the local authorities.

This reaction may be understood when reviewing the $2006 \mathrm{Homi}$ cide Report for Oakland. Five-year averages compiled for 2001-2006 showed that $30 \%$ of murder victims were between the ages of 18 to 24 and another $33 \%$ were between 25 and 34 years old. Males made up 96\% of suspects and $88 \%$ of victims. The five-year average for homicide victims in Oakland breaks down as follows: 77\% Black, $15.4 \%$ Hispanic, $3.2 \%$ White, $2.8 \%$ Asian and $1.6 \%$ Unknown. The five-year average for homicide suspects in Oakland breaks down as follows: $64.7 \%$ Black, 8.6\% Hispanic, $0.2 \%$ White, $2.0 \%$ Asian and 24.4\% Unknown. In 2006, during the height of the Hyphy Movement, homicide victims under the age of 18 tripled compared to previous years." 43 Specifically, Hyphy encompassed the angry unified response to yet another senseless murder and the end of Grant's life represented a particularly galvanizing tragedy.

Hip hop as an ambivalent and ubiquitous art form has proven to have the power to serve as a platform that produces unified communities and social awareness in relation to injustice. The Bay Area community organizations I have highlighted used the Hyphy Movement as a strategic tool to collaborate with some of the founding fathers of Bay Area hip hop to create engaging educational activism as justice for Oscar Grant III. It was the people influenced by the Hyphy mentality of the movement whether perceived as edifying or destructive, who utilized it in shifting the revolutionary consciousness of young people advocating for social justice. The Black Lives Matter network in the Bay Area is now a

41 Mistah F.A.B. and Amp Live (Zion I) - "Oscar Grant III Tribute (My Life)" ft. Jennifer Johns \& Codany Holiday, January 2009.

42 Octavia Bostick, "HYPHY: The Bay's Hip Hp Revenge," AllHipHop.com, February 162006.

432006 Homicide Report: An Analysis of Homicides in Oakland from January through December, 2006. February 82007. 
seed of the legacy of past counter-cultural social movements that originated from this region and is made up of the same people who have brought an unprecedented amount of attention to the egregious acts of violence involving police.

Oscar Grant III was murdered in 2009, the same year Obama was inaugurated as president. Eight years later the United States of America is currently enduring a heightened sense of Black lives still not mattering as Obama ends his term. R.I.P. to all lives lost due to police violence.I 